\title{
TRIP型複合組織鋼の伸びフランジ性に及ぼす 温間加工の影響
}

\author{
長坂 明彦*・杉本 公一*2・小林 光征*2・橋本 俊一*3
}

Effects of Warm Forming on Stretch-flangeability of a TRIP-aided Dual-phase Sheet Steel Akihiko Nagasaka, Koh-ichi Sugimoto, Mitsuyuki Kobayashi and Shun-ichi Hashimoto

Synopsis : To improve the stretch-flangeability of a high strength TRIP-aided dual-phase (TDP) sheet steel, the effects of forming temperature, forming rate and clearance on the stretch-flangeability were investigated. Warm hole-punching at $150-200^{\circ} \mathrm{C}$ and successive warm hole-expanding at about $150^{\circ} \mathrm{C}$ increased considerably the stretch-flangeability. The warm hole-punching minimized void initiation at matrix/second phase interface, work hardening and a depth of damage layer at hole surface by suppressing the strain-induced transformation in an early stage. Also, it increased the volume fraction of untransformed retained austenite, which contributes to large stretch-flangeability. The warm hole-expanding improved the localized ductility due to the transformation induced plasticity. When a clearance between punch and die was about $10 \%$, the largest stretch-flangeability was obtained with the minimum surface damage on hole-punching. Punching rate influenced hardly upon the stretch-flangeability, although it did somewhat on surface damage.

Key words : stretch-flangeability ; warm forming ; retained austenite ; stability ; transformation-induced plasticity ; strain-induced transformation; high strength steel.

\section{1. 緒言}

乗用車の衝撃安全性および軽量化を目的として開発され た高強度鋼板の中で，残留オーステナイト $\left(\gamma_{\mathrm{R}}\right)$ の変態誘起 塑性(TRIP) ${ }^{1)}$ 有効に利用したTRIP型複合組織鋼板 ${ }^{2-9)}$ (TDP鋼板) はとくに優れた深絞り性7,9) と張出し性6,8)を有す る。現在, 軽量化効果の最も期待できる足回り部品への適 用研究が積極的に行われているが，伸びフランジ性が低い という報告が多く10,11)，その改善が求められている。

一般に高強度複合組織鋼ではフェライト $\left(\alpha_{\mathrm{f}}\right)+$ ベイナイト $\left(\alpha_{\mathrm{b}}\right)$ 複合組織鋼および $\alpha_{\mathrm{f}}+\alpha_{\mathrm{b}}+$ マ ルテンサイト $\left(\alpha_{\mathrm{m}}\right)$ 複合組 織鋼の伸びフランジ性がとくに優れている10)。TDP鋼の組 織 $\left(\alpha_{\mathrm{f}}+\alpha_{\mathrm{b}}+\gamma_{\mathrm{R}}\right)$ は，これらの鋼に類似するにもかかわらず その伸びフランジ性が $\alpha_{\mathrm{f}}+\alpha_{\mathrm{m}}$ 複合組織鋼と同程度に低い理 由は, ひずみ誘起変態 (SIT)により生じた $\alpha_{\mathrm{m}}$ が高炭素濃度 を有するため極めて硬く， $\alpha_{\mathrm{f}}$ 母相との界面でボイドが形成さ れやすいためであると考えられている ${ }^{10,11)} 。 \gamma_{\mathrm{R}}$ のひずみ誘起 变態およびそれによるTRIP効果はとくに加工温度によって

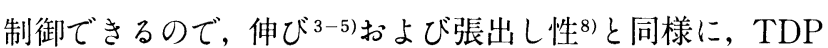
鋼の伸びフランジ性も温間加工によって改善できると予想 される。

このような観点より，本研究ではTDP鋼の伸びフランジ
性に及ぼす温間加工の効果を,パンチ打抜き穴損傷特性（加 工変質層哚さ， $\gamma_{R}$ の変態量, ボイド発生状況) および穴広げ 特性(穴広げ率，加工荷重)の両面より詳細に調查した。ま た, 加工速度およびクリアランスの影響も同時に調查した。 さらに,これらの結果を $\gamma_{\mathrm{R}}$ のSIT挙動から考察した。

\section{2. 実験方法}

供試鋼には $0.20 \mathrm{C}-1.50 \mathrm{Si}-1.50 \mathrm{Mn}-0.015 \mathrm{P}-0.0012 \mathrm{~S}$ $0.041 \mathrm{Al}$ ，mass\%の化学組成を有する真空溶製された厚さ $30 \mathrm{~mm}$ のスラブを用いた。これをまず, $1200^{\circ} \mathrm{C} て ゙$ 均質化処理 後，4パスで $3.2 \mathrm{~mm}$ まで熱間圧延を行った。最終圧延温度

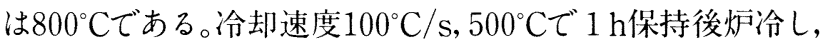
酸洗後, 室温で $1.2 \mathrm{~mm}$ まで冷間圧延を行った後, 以下の熱 処理を施した。すなわち, $780^{\circ} \mathrm{C} て ゙ 1200 \mathrm{~s} の 2$ 相域焼なまし後, $400^{\circ} \mathrm{C}$ 塩浴中に急冷, その温度で1000s保持後油冷のオース テンパ処理を施し， $\alpha_{\mathrm{f}}+\alpha_{\mathrm{b}}+\gamma_{\mathrm{R}} 3$ 相組織を有するTDP鋼 した。以下では， $\alpha_{\mathrm{b}}+\gamma_{\mathrm{R}}$ 相を第 2 相と呼ぶ。

引張試験には，圧延方向に平行に作製したJIS13B号引張 試験片 (幅 $12.5 \mathrm{~mm}$, 標点間距離 $50 \mathrm{~mm}$ ) を用い,インストロ ン型万能試験機により行った。試験片の加熱には，一対の プレート状ストリップヒーターを用い，試験前の保持時間

平成 8 年11月25月受付 平成 9 年 3 月 7 日受理（Received on Nov. 25, 1996; Accepted on Mar. 7, 1997)

* 長野工業高等専門学校機械工学科 (Department of Mechanical Engineering, Nagano National College of Technology, 716 Tokuma Nagano 381)

* 2 信州大学工学部 (Faculty of Engineering, Shinshu University)

* 3 (株) 神戸製鎆所鉄鋼事業本部 (Iron and Steel Division, Kobe Steel, Ltd.) 

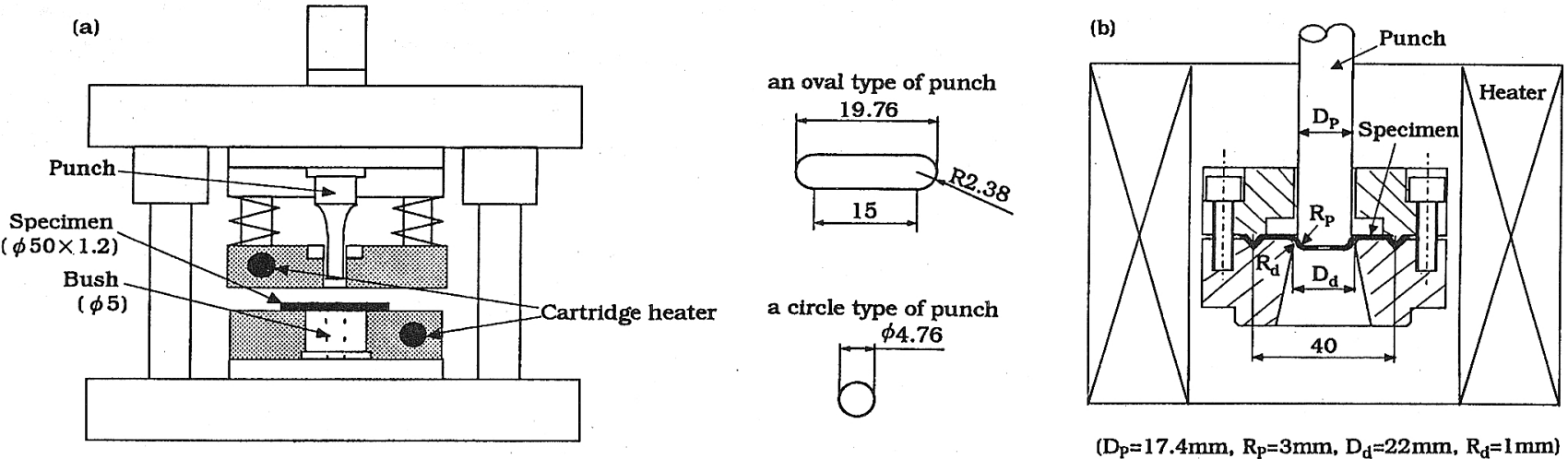

Fig. 1. Experimental apparatus for (a) warm hole-punching and (b) warm hole-expanding.

は30min とした。試験温度は20〜 $250^{\circ} \mathrm{C}$ 範囲，クロスヘッ

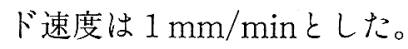

打抜き扔よび穴広げ試験には，直径 $50 \mathrm{~mm}$ ，板厚 $1.2 \mathrm{~mm}$ の円盤状小型試験片を用いた。試験装置には, Fig. 1 の装置 を用いた。いずれの試験にも，グラフアイト系潤滑剤を使 用した。打抜き加工に括いて，打抜き温度は $T_{\mathrm{P}}=20 \sim 250^{\circ} \mathrm{C}$ の範囲，打抜き速度は $V_{\mathrm{P}}=1,10,100 \mathrm{~mm} / \mathrm{min} の 3$ 条件, クリアランスは $c=5 \sim 30 \%$ 範囲とした。試験片の加熱は, ストリッパプレートとダイプレートに差込んだカートリッ ジヒーターにより行った。打抜き金型のブッシュ径は $5.0 \mathrm{~mm}$ 一定のダイ基準とし，パンチ直径を4.88，4.76, 4.52, 4.28 $\mathrm{mm} の 4$ 種類とした。

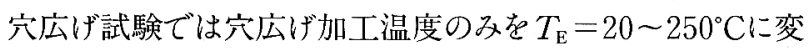

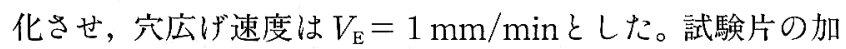
熱は環状炉によって行い，打抜き穴のダレ部をパンチ側と した。なお，両試験温度は試験片表面温度を意味する。

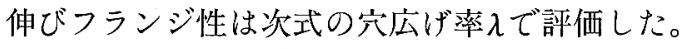

$\lambda=\left(d_{\mathrm{f}}-d_{0}\right) / d_{\mathrm{o}} \times 100 \%$

ここで， $d_{0}, d_{\mathrm{f}}$ はそれぞれ初期穴径, き裂発生時の穴径で 市る。

$\lambda に$ に打抜き時の表面損傷が重要な役割を演ずる。このた め, 打拔き穴表面層の $\gamma_{\mathrm{R}}$ 量変化, 硬さ変化およびボイドの 発生状況を詳細に調査した。 $\gamma_{\mathrm{R}}$ 量の測定精度を高くするた め,Fig. 1 (a)の長円形パンチで打抜いた直線状の表面(せん 断部, 破断部)において， $\gamma_{\mathrm{R}}$ の変態量を測定した。すなわち， 電解研磨法により表面索順次除去し, X線回折法 ( 5 ピーク 法 ${ }^{22)}$ により $\gamma_{\mathrm{R}}$ 量を順次測定した。さらに, SEM観察および マイクロビッカース硬さ测定も必要に応に゙行った。

\section{3. 実験結果および考察}

\section{$3 \cdot 1$ 微細組織と引張特性}

Fig. 2 にTDP鋼の微細組織を示す。本鋼では26.1 vol\%の 第 2 相 $\left(\alpha_{\mathrm{b}}+\gamma_{\mathrm{R}}\right)$ か $\alpha_{\mathrm{f}}$ 粒界に沿って存在する。 $\gamma_{\mathrm{R}}$ は $\alpha_{\mathrm{b}}$ と隣接 または孤立して粒子状に存在し，その体積率 $f_{\gamma_{\mathrm{O}}}{ }^{12)}$ は $7.9 \mathrm{Vol} \%$,

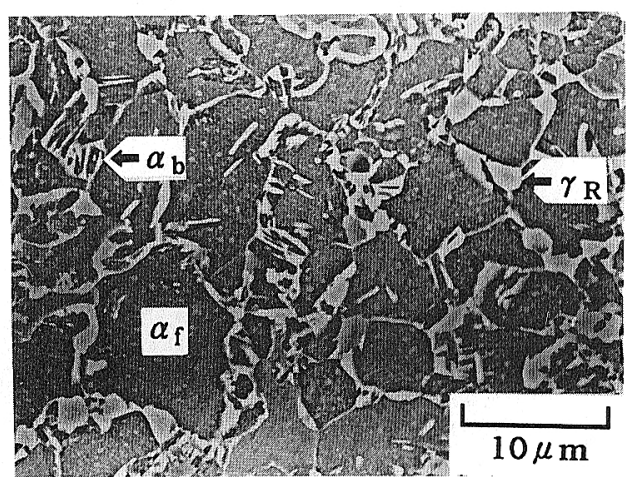

Fig. 2. Scanning electron micrograph of as-austempered TDP steel, in which " $\alpha_{\mathrm{f}}$ ", " $\alpha_{\mathrm{b}}$ " and " $\gamma_{\mathrm{R}}$ " represent ferrite matrix, bainite island and retained austenite particle, respectively.

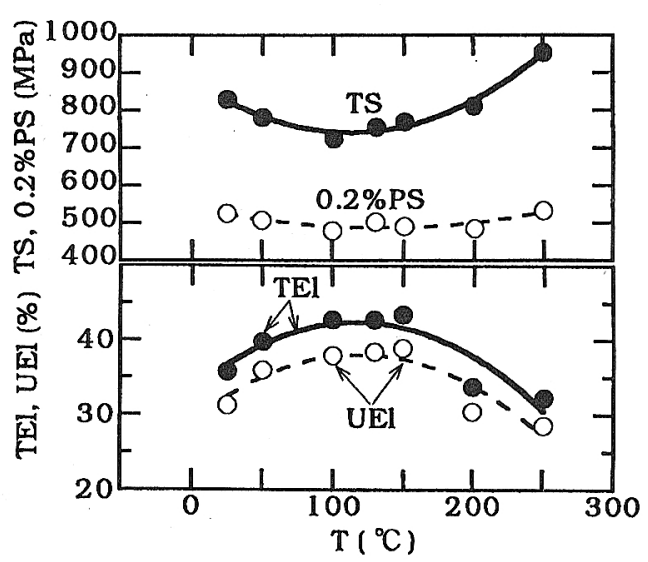

Fig. 3. Variations in $0.2 \%$ offset proof stress $(0.2 \%$ $P S)$, tensile strength (TS), total elongation $(T E l)$ and uniform elongation (UEl) with testing temperature $(T)$.

炭素濃度 $C_{\gamma_{0}}{ }^{4}$ 虫 $1.38 \mathrm{mass} \%$ あるあ。この $C_{\gamma_{0}}$ から $\gamma_{\mathrm{R}}$ の $M_{\mathrm{S}}$ 点 はー $37^{\circ} \mathrm{C}$ と計算される

Fig. 3 にTDP鋼の引張特性の変形温度依存性を示す。変

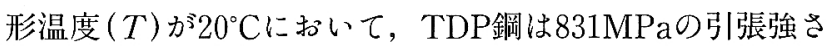
$(T S)$ と約 $36 \%$ の大な全伸び $(T E l)$ を有する。変形温度が 高くなるにつれて全伸びは大きくなり, 変形温度が $100 \sim 150^{\circ} \mathrm{C}$ の範囲で最大となる。引張強さはこれと逆の変形温度依存 
性を示しこの温度範囲でほぼ最小となる。このような引 張特性の変形温度依存性は安定な $\gamma_{\mathrm{R}}$ t含むTDP鋼に特有の 現象であり，他の複合組織鋼には現れない8)。

一般に, $M_{\mathrm{s}}$ 点以上の温度範讲では, TDP鋼の $\gamma_{\mathrm{R}}$ 量 $f_{\gamma}$ はひ ずみととともに(2)式にしたがって減少するふ。

$$
\log f_{r}=\log f_{r_{0}}-k \cdot \varepsilon
$$

ここで $f_{r_{0}}$ は初期 $\gamma_{\mathrm{R}}$ 量である。kはひずみ誘起変態定数で, その值は $\gamma_{\mathrm{R}}$ のひずみ誘起変態が抑制されるほぼ小さくなる。 引張変形下において, $k$ 值の加工温度依存性を調查したとこ 万, Fig. 4 のように, $T_{\mathrm{s}}=100 \sim 150^{\circ} \mathrm{C} て ゙ k$ 值の最小值 $k_{\min }$ が 得られ,この温度はTElが最大となる温度 (Fig. 3 ) とほぼ一 致した。したがって，100〜 $150^{\circ} \mathrm{Cにおいては，} \gamma_{\mathrm{R}}$ のひずみ 誘起変態がくびれが生ずる高ひずみ域で効果的に起こり, これによるひずみ硬化率の増加および母相／第 2 相界面で のボイドの発生・成長が抑制されることにより，TElが著し く改善されたと考えることができる3-5)。同時に生ずる低い $T S$ 硬い $\alpha_{\mathrm{m}}$ 相が低ひずみ域でわずかしか生じなかった $\left(\alpha_{\mathrm{m}}\right.$ 硬化が小さかた)ためと考えられる。なお, 準安定オース テナイト鋼ではひずみ誘起変態は $M_{\mathrm{s}}$ 点と $M_{\mathrm{d}}$ 点の間の温度範 囲で起こり, 高温ほどひずみ誘起マルテンサイト変態 (SIMT) は抑制される ${ }^{13)}$ 。TDP鋼では $M_{\mathrm{d}}$ 点以下の $200^{\circ} \mathrm{C}$ 以上でひず み誘起ベイナイト変態(SIBT) を生ずるため3)，これと異な る現象が生じたものである。

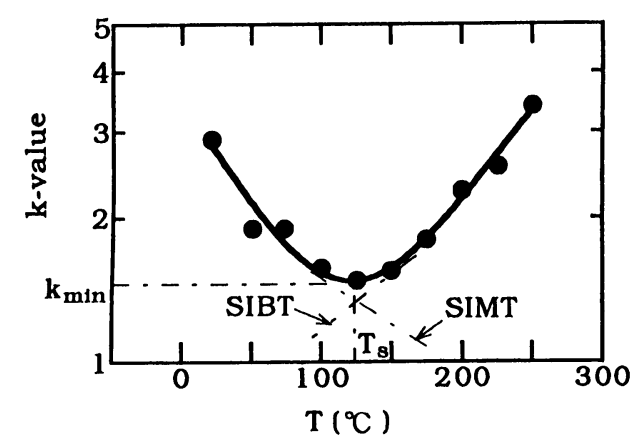

Fig. 4. Variation in $k$-value in tension with testing temperature $(T)$, in which "SIMT" and "SIBT" represent strain-induced martensite and bainite transformations, respectively.

\section{$3 \cdot 2$ 打抜き特性に及ぼす打抜き温度の影響}

Fig. 5 に, TDP鋼板を種々の加工温度 $T_{\mathrm{P}}$ で打抜き加工し たときの (a) 打抜きせん断応力 $\tau_{\mathrm{p}},(\mathrm{b})$ 加工変質層深さ $l^{*}$ お よび (c) 最大平均硬さ $\overline{H V}_{\text {max }}$ を示す。ここで, $\overline{H V}_{\text {max }}$ は打抜 き表面から50 $\mu \mathrm{m}$ 内部をマイクロビッカース硬さ試験機(荷 重 $0.245 \mathrm{~N}$ )にて測定した。 $l^{*}$ はFig. 6 (a)のように， $\gamma_{\mathrm{R}}$ 量の 变化が認められなくなる臨界深さである。参考のため, Fig. 6 中には, ドリル切削穴の $l^{*}$ 示す。これらの図から, 以下 のことがわかる。

（1） $\tau_{\mathrm{P}}$ は加工温度が $100 \sim 150^{\circ} \mathrm{C}$ まで低下し，一旦一定とな るが，TS (Fig. 3 ) と異なりそれ以上の温度でさらに低下す る。

( 2 ) l*は150 200ㄷで最小となる。l゙に及ぼす加工温度の

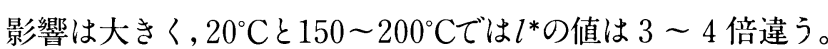

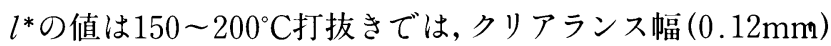
の值まで低下寸る。しかし，切削加工のときの $l^{*}(0.028 \mathrm{~mm})$

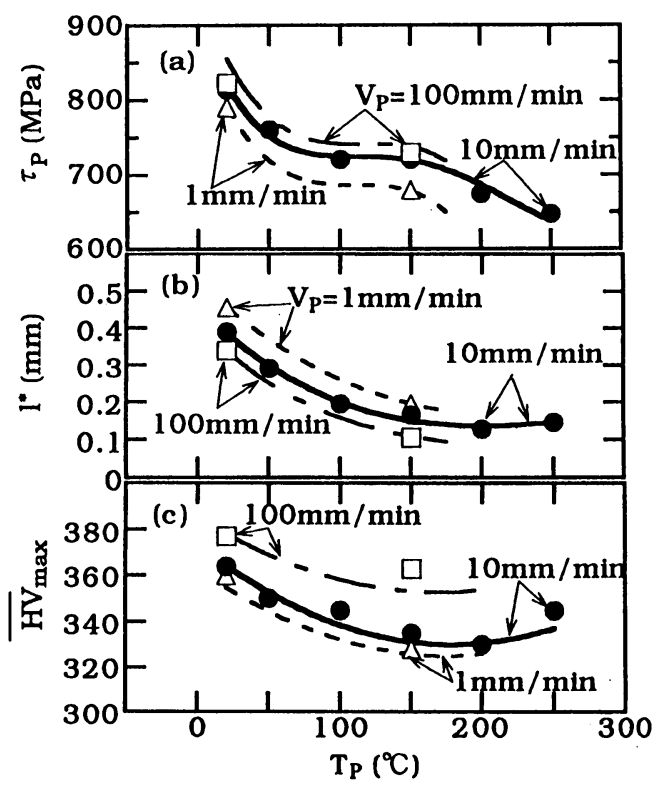

Fig. 5. Variations in (a) punching shear stress $\left(\tau_{\mathrm{P}}\right)$, (b) critical damage depth $\left(l^{*}\right)$ and (c) maximum mean hardness $\left(H V_{\max }\right)$ in hole-surface layer of TDP steel with punching temperature $\left(T_{\mathrm{P}}\right)$ and punching speed $\left(V_{\mathrm{P}}\right)$ under $c=$ $10 \%$.

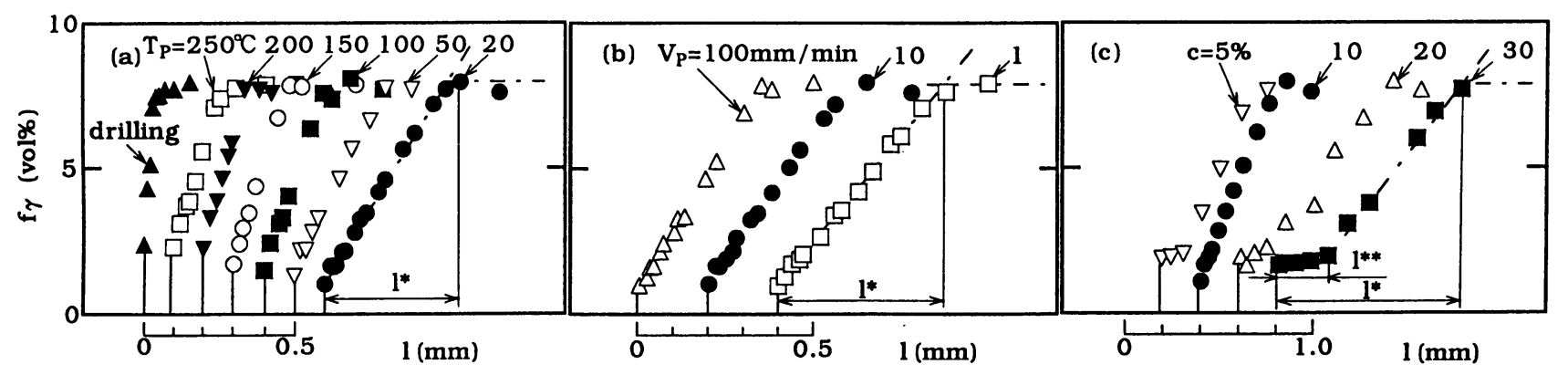

Fig. 6. Depth distribution of $\gamma_{\mathrm{R}}$ content in a hole surface layer punched (a) at various temperatures between 20 and $250^{\circ} \mathrm{C}\left(c=10 \%, V_{\mathrm{P}}=10 \mathrm{~mm} / \mathrm{min}\right)$, (b) at various punching speed $\left(T_{\mathrm{P}}=20^{\circ} \mathrm{C}, c=10 \%\right)$ or $(\mathrm{c})$ at various clearance $\left(T_{\mathrm{P}}=20^{\circ} \mathrm{C}, V_{\mathrm{P}}=10 \mathrm{~mm} / \mathrm{min}\right)$, in which $l^{*}$ represents critical depth of damage layer. Drilling is conducted at $20^{\circ} \mathrm{C}$. 

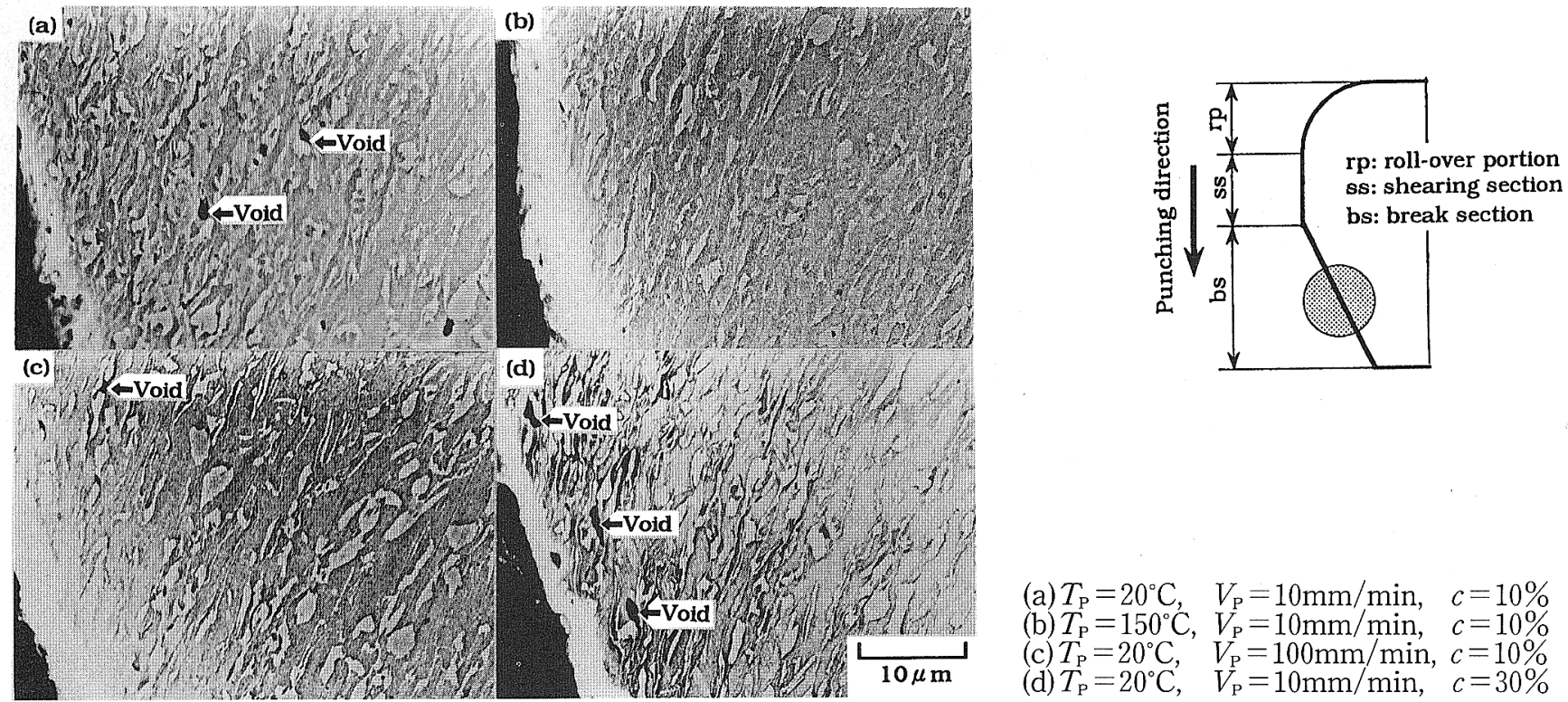

Fig. 7. Scanning electron micrographs showing cross section of hole surface in TDP steels punched under various conditions.

よりはかなり大きい。

(3) $\overline{H V}_{\text {max }}$ は 150 〜 $200^{\circ} \mathrm{C}$ で最小となる。打抜き温度にと もなう $\overline{H V}_{\max }$ の変化量は小さいが,これは打抜き時のせん 断ひずみが大きいため, 表面の未変態 $\gamma_{\mathrm{R}}$ 量の差が小さくな った(Fig. 6 (a))ことによると予想される。

このような $l^{*} と \overline{H V}_{\text {max }}$ の打抜き温度依存性は後述の穴広 げ率の打抜き温度依存性と活澄一致するので，次に述べる ボイドの発生頻度とともに，表面損傷を小さくすることが 穴広げ率の改善につながると考允てよいであ万う。

Fig. 7 に, TDP鋼を $20^{\circ} \mathrm{C}$ または $150^{\circ} \mathrm{C} て ゙$ 打抜き加工したと きの打抜き穴表面加工層断面のSEM写真を示す $(c=10 \%$, $\left.V_{\mathrm{P}}=10 \mathrm{~mm} / \mathrm{min}\right) 。$ 。ずれの加工温度でも, 致命的な大きな ボイドは観察されず，1 $\mu \mathrm{m}$ 以下のごく小さいボイドのみし

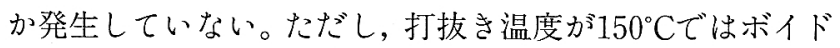
の数扔よび大きさが減少していることが認められる。この 事実は, TDP鋼では打抜き時にボイドが発生しやすいとい 弓一般的な予想と大きく異なる。150 ${ }^{\circ} \mathrm{C}$ 打抜きでボイドの数, 大きさが減少した理由として, 単軸引張りの場合4) 同様に, ボイドの発生源つまり応力集中源となる硬質の $\alpha_{\mathrm{m}}$ が生に゙に くいことおよび高ひずみ域でのSITが局所的応力集中を緩 和するためであると考えられる。またこれらの鋼では, 明膫な塑性流動も起きていることが観察される。この塑性 流動は穴広げ時に主き裂の進展を妨害し, 穴広げ率を高为 る効果が期待できるが，穴広げ率に対しに゙の程度貢献する かを評価することは難しい。

本鋼では打拔き温度が $150 \sim 200^{\circ} \mathrm{C}$ 範囲で， $l^{*} \varepsilon \overline{H V}_{\text {max }}$ が小さく，未变態 $\gamma_{\mathrm{R}}$ 量が多くなった。このような表面損傷 は $\gamma_{\mathbb{R}}$ のひずみ誘起変態が最も抑制される温度 $(k$ 值が最小 なる温度 $T_{\mathrm{S}}$ ) と一致すると予想されたが, 実際にはその $T_{\mathrm{S}}$ よ り $50^{\circ} \mathrm{C}$ 程度高い温度で得られた。Fig. 5 から， $\tau_{\mathrm{p}}$ は $T_{\mathrm{S}}$ に相当
する $100 \sim 150^{\circ} \mathrm{C}$ まで一旦低下するが，それ以上の温度でさら に低下している。舲の低下はひずみ誘起変態の抑制 (未変態 $\gamma_{\mathrm{R}}$ 量を増加) と, これに関係する加工硬化の抑制を意味する。 これが，打拔き損傷の最適加工温度を高温側にずらせた主 な原因と考えられる。䀡が $200^{\circ} \mathrm{C}$ 以上の打抜き温度で低下し た原因について蜆在検討中である。な和，せん断変形で は平均垂直応力 $\sigma_{\mathrm{m}}$ は 0 となり, 単軸引張变形時より小さく なるため，これは逆に $T_{\mathrm{S}}$ を低下させる $\left(\text { 約 } 15^{\circ} \mathrm{C}\right)^{8)}$ 。また，加 工速度が大きくなること(加工発熱が大きくなること)は は值 を低めるが $k_{\min }$ が現れる温度 $T_{\mathrm{S}}$ 変化させない3)。

\section{$3 ・ 3$ 穴広げ特性に及ぼす打抜き時のクリアランスと 打抜き速度の影響}

Fig. 8 に, TDP鋼板をクリアランス $c$ を種々变えて $20^{\circ} \mathrm{C} て ゙$ 打拢き加工したをきの (a) 打抜きせん断応力 $\tau_{\mathrm{P}}$ 和よび (b) 加 工変質層深さ $l^{*}$ と最大平均硬さ $\overline{H V}_{\text {max }}$ を示す。 $l^{*}$ 蛙クリア ランスの増加に伴い増加するが，c=5\%ではかえってl゙が 堌加するため, $c=10 \%$ で最小となる。 $c=5 \%$ の大きい $l^{*}$ 值は 2 次せん断面の発生などにより, Fig. 6 (c) にみるよ うに， $\gamma_{\mathrm{R}}$ のSITが異常に生ずる領域l゙が現れたことによる と考学られる。 $\overline{H V}_{\max }$ も $c=10 \%$ で最小となるが $150^{\circ} \mathrm{C}$ 打抜きでは $c=20 \%$ に扔いても $c=10 \%$ の場合と同様の低い $\overline{H V}_{\text {max }}$ t示す。

クリアランスを変化させた場合の打抜き穴表面の断面を 観察したところ，クリアランスが大きくなるにしたがい， 塑性流動が不明瞭となる傾向が認められた。しかし，ボイ ドの大きさ，数などの差虫虫っきりしなかうた。

Fig. 9 に, 穴広げ率に及ばすクリアランスの影響老示す。

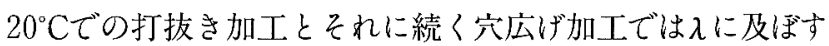

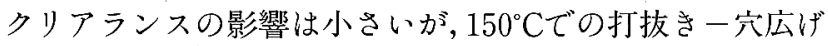
加工では顕著に現れる。このときの最適クリアランスは $20^{\circ} \mathrm{C}$ 


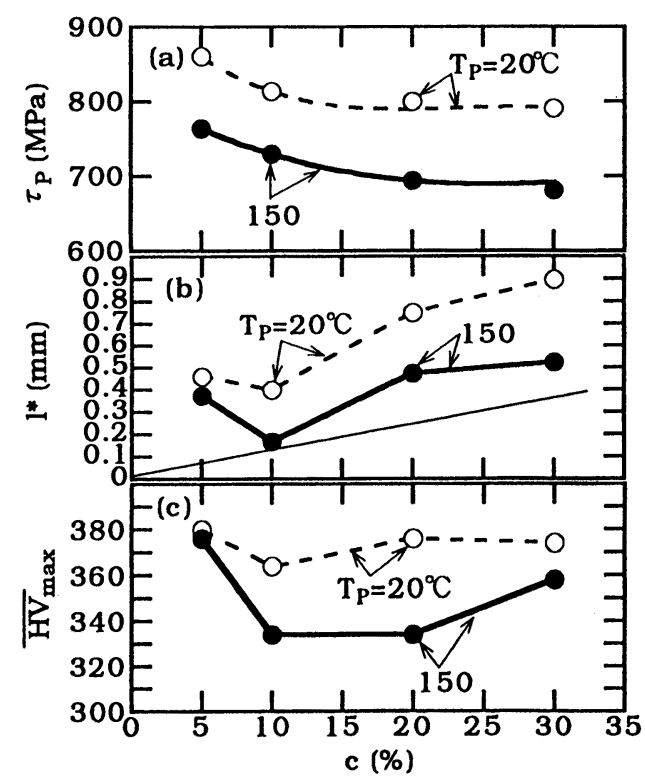

Fig. 8. Effect of clearance on (a) punching shear stress $\left(\tau_{\mathrm{P}}\right),(\mathrm{b})$ critical damage depth $\left(l^{*}\right)$ and (c) maximum mean hardness $\left(H V_{\max }\right)$ in hole -surface layer of TDP steels punched at $T_{\mathrm{P}}=20^{\circ} \mathrm{C}$ or at $150^{\circ} \mathrm{C}$. A straight line in (b) represents a product of clearance and thickness of TDP steel.

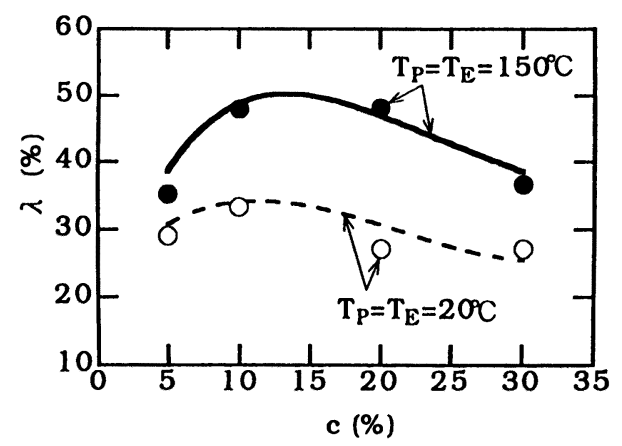

Fig. 9. Effect of clearance $(c)$ on hole-expanding ratio $(\lambda)$ of TDP steel. $\left(V_{\mathrm{P}}=10 \mathrm{~mm} / \mathrm{min}\right.$, $\left.V_{\mathrm{E}}=1 \mathrm{~mm} / \mathrm{min}\right)$

および $150^{\circ} \mathrm{C}$ 加工でそれぞれ $c=10 \% ， 10 〜 20 \%$ なり，打 抜き損傷が最小となるクリアランスと一致する。

打抜き特性に及ぼす加工速度の影響を Fig. $5 ， 6$ (b) に示 寸。これらの図から，高速打抜き加工は打抜き穴表面層の $l^{*}$ を小さくするが， $\overline{H V}_{\text {max }}$ を高めることが認められる。 $l^{*}$ の低下は多分, 断熱発熱により $\gamma_{\mathrm{R}}$ のSITが抑制され, 未変態 $\gamma_{\mathrm{R}}$ 量が増加し，かつボイドの発生が抑制された金属学的要 因々、高速せん断により塑性変形域が狭くなる力学的要因 ${ }^{14)}$ から生じたものと考えることができる。

加工速度が大きい場合についても表面加工層断面を観察 したが，加工速度が $10 \mathrm{~mm} / \mathrm{min}$ 以上では，塑性流動がより 明瞭に現れるとともに, ボイドの大きさ, 数も減少するこ とが認められた（Fig. 7 (c)）。

穴広げ率に及ぼす打抜き速度 $V_{\mathrm{P}}$ の影響も調查したが，明

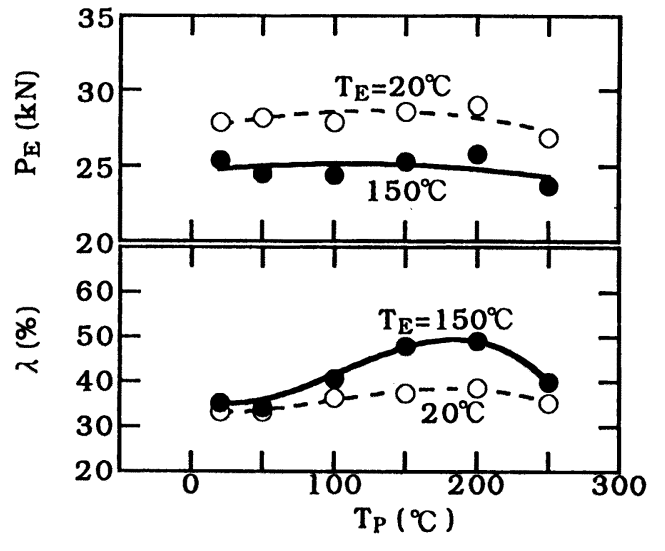

Fig. 10. Effect of punching temperature $\left(T_{\mathrm{P}}\right)$ on maximum hole-expanding load $\left(P_{\mathrm{E}}\right)$ and hole-expanding ratio $(\lambda)$ of TDP steel, in which $T_{\mathrm{E}}$ represents hole-expanding temperature. $\left(V_{\mathrm{P}}=10 \mathrm{~mm} / \mathrm{min}, V_{\mathrm{E}}=1 \mathrm{~mm} / \mathrm{min}\right)$,

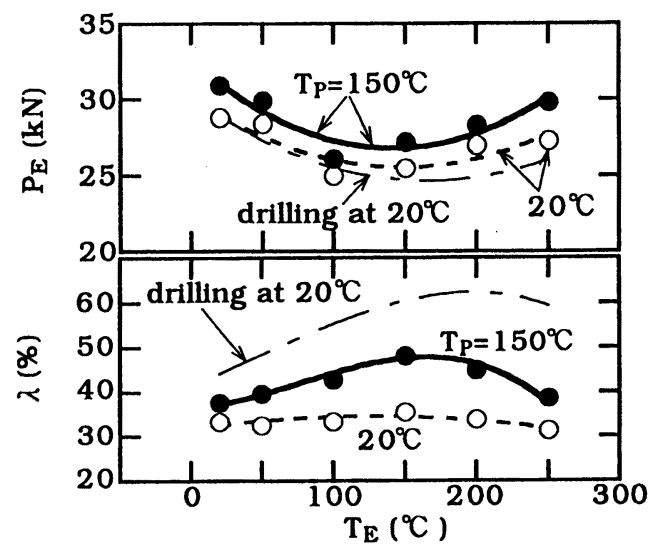

Fig. 11. Effects of punching temperature $\left(T_{\mathrm{P}}\right)$ and expanding temperature $\left(T_{\mathrm{E}}\right)$ on maximum hole-expanding load $\left(P_{\mathrm{E}}\right)$ and hole-expanding ratio $(\lambda)$ of TDP steel. $\left(V_{\mathrm{P}}=10 \mathrm{~mm} /\right.$ $\min , V_{\mathrm{E}}=1 \mathrm{~mm} / \mathrm{min}$ )

瞭な $V_{\mathrm{P}}$ 依存性は認められなかった。高速打抜きは入の増加 に貢献しなかったが，これは高速打抜きでは $\overline{H V}_{\text {max }}$ の増加 が大きく、これがl゙を低下させた効果を打ち消したものと考 えている。

3 ・4 穴広げ特性に及ぼす打抜き温度と穴広げ温度の影響 穴広げ率入および最大穴広げ荷重 $P_{\mathrm{E}}$ に及ぼす打抜き温度お よび穴広げ温度の影響をそれぞれFig.10, 11に示す $(c=10 \%$,

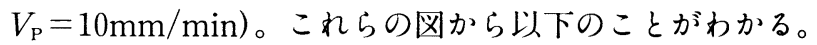

( 1 ) $150 \sim 200^{\circ} \mathrm{C}$ 温間打抜きと約 $150^{\circ} \mathrm{C}$ 温間穴広げの併 用により入值は著しく改善される。片方のみの温間加工は効 果がかさい。

(2) $\lambda$ の打抜き温度依存性 (Fig.10) はFig. 5 の $l^{*}, \overline{H V}_{\text {max }}$ の打抜き温度依存性とほぼ一致する。これは, $\lambda$ の最適打抜 き温度は打抜き表面損傷を最小とする温度であることを意 味する。

( 3 ) 温間併用加工時の入值は切削穴の室温穴広げ加工時 


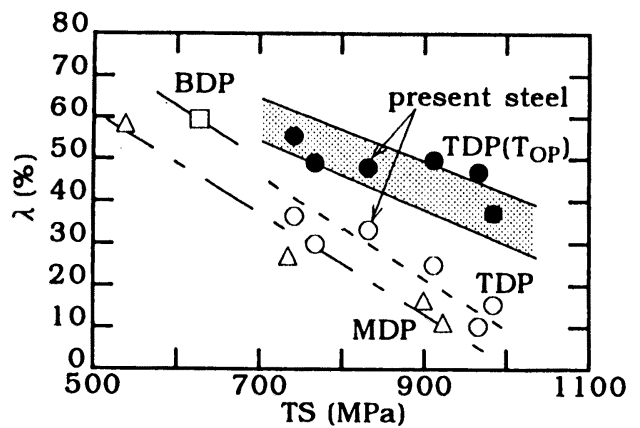

Fig. 12. Comparison of hole-expanding ratio $(\lambda)$ of TDP, BDP $\left(\alpha_{\mathrm{f}}+\alpha_{\mathrm{b}}\right)$ and MDP $\left(\alpha_{\mathrm{f}}+\alpha_{\mathrm{m}}\right)$ steels formed at $20^{\circ} \mathrm{C}$ (open marks) or at optimum forming temperature $\left(T_{\mathrm{OP}}\right.$, solid marks) as a function of $T S$.

の入值とほぼ同等レベルまで改善される。

$\lambda に$ 对する最適穴広げ加工温度は $T E l$ 同様に, $k$ 值が最 小となる温度 $T_{\mathrm{s}}$ とほぼ一致する (Fig. 4 )。したがって, 応力 状態の相違を別にすれば, 穴広げ率入の温間加工による改善 も $T E l$ と同様な考え方が適用できるであろう。すなわち， $\gamma_{\mathrm{R}}$ のひずみ誘起変態が高ひずみ域で効果的に起こり，これに よる延性の増加と応力集中の緩和 ${ }^{4}$ が 母相／第 2 相界面での ボイドの成長を抑制する。ただし，打抜き穴表面層におい てすでにかなりの加工硬化とボイドの発生が生じている場 合 $\left(20^{\circ} \mathrm{C}\right.$ 打抜きの場合) は $\gamma_{\mathrm{R}}$ のひずみ誘起変態の効果は小さ く，また穴広げ温度依存性も小さくなる。

一般に, $\lambda$ は局部伸び $(L E l)$ と相関があり, 局部伸びが大

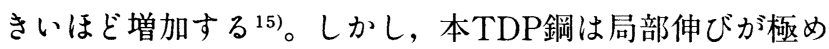
て小さい特異な材料であり, $\lambda$ に对しては一様伸び $(U E l)$ ま たは全伸びとの相関が大きいと考えられる。

著者らが本TDP鋼と同一の条件で別に行った $\alpha_{\mathrm{f}}+\alpha_{\mathrm{b}}$ 複合 組織鋼 (BDP鋼) および $\alpha_{\mathrm{f}}+\alpha_{\mathrm{m}}$ 複合組織鋼 $(\mathrm{MDP}$ 鋼) の $\lambda$ 值 との比較を Fig.12 ${ }^{16)}$ に示す。図中には, Si, Mn添加量の異

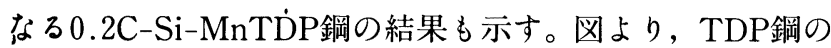
$20^{\circ} \mathrm{C}$ 加工の穴広げ率は従来の報告 ${ }^{10,11)}$ のうに, MDP鋼よ り少し優れている程度であるが，温間打抜き加工と温間穴 広げ加工の併用により, 最適加工温度 $T_{\mathrm{OP}}$ での值はBDP鋼に 匹敵するまでに改善されることがわかる。つまり，本TDP 鋼は本質的には伸びフランジ性に優れた鋼であることがわ かる。

\section{4. 結言}

TDP鋼の伸びフランジ性に及ぼす打抜き時および穴広げ 時の加工温度, 加工速度, クリアランスの影響支詳細に調 查した。主な結果は以下の通りである。

(1) TDP鋼の穴広げ率は150 $200^{\circ} \mathrm{C}$ の温間打抜きと約 $150^{\circ} \mathrm{C}$ 温間穴広げの併用により著しく改善された。このと きの打抜き加工時の最適クリアランスは約 $10 \sim 20 \%$ であり, 打拔き加工速度の影響は小さかった。

(2) 温間加工により得られるTDP鋼の穴広げ率は, BDP 鋼に匹敵，るしくはこれを上回った。この事実は，本質的 にはTDP鋼は張出し性, 深絞り性とともに伸びフランジ性 にも優れた高強度鋼板であることを示唆している。

(3) 温間打抜きは $\gamma_{\mathrm{R}}$ のSITを抑制し, 打抜き穴表面層の加 工硬化およびボイドの発生頻度を小さくする。また, TRIP による変形能の増加により,明瞭な塑性流動を生じさせる。

(4) 温間穴広げは効果的なTRIPにより高ひずみ域でのひ ずみ硬化の低下を抑制するとともに，ボイドの成長を抑制 する。

\section{文献}

1) V.F.Zackay, E.R.Parker, D.Fahr and R.Busch: Trans.ASM, 60 (1967), 252.

2 ) O.Matsumura, Y.Sakuma and H.Takechi : Trans. Iron Steel Inst. Jpn., 27 (1987), 570

3 ) K.Sugimoto, M.Kobayashi and S.Hashimoto: Metall.Trans., 23A (1992), 3085.

4 ) K.Sugimoto, N.Usui, M.Kobayashi and S.Hashimoto: ISIJ Int., 32 (1992), 1311.

5 ) K.Sugimoto, M.Misu, M.Kobayashi and H.Shirasawa: ISIJ Int., 33 (1993), 775.

6 ) O.Matsumura, Y.Sakuma, Y.Ishii and J.Zhao: ISIJ Int., 32 (1992), 1110.

7 ) 樋渡俊二, 高橋 学, 片山知久, 臼田松男 : 塑性 $と$ 加工, 35 (1994), 1109.

8 ) K.Sugimoto, M.Kobayashi A.Nagasaka and S.Hashimoto: ISIJ Int., 35 (1995), 1407.

9 ）松村 理，大上哲朗，雨池龍男：鉄と鋼， 79 (1993), 209

10）三村和弘, 宮原征行, 白沢秀則, 横井利雄, 柴田善一, 井上尚和 : 材料とプロセス，5 (1992), 1859

11）広瀬洋三, 中居修二, 福山東成, 須藤誠一, 上野行一：塑性 $と$ 加 工, 35 (1994), 1071.

12）円山 弘：熱処理, 17 (1977), 198.

13) I.Tamura, T.Maki and H.Hato : Trans. Iron Steel Inst. Jpn., 10 (1970), 163.

14）中川威雄, 阿部邦雄, 林 程: 薄板のプレス加工, 実教出版, (1985), 47.

15）浅野裕秀，潮田浩作，石井良男：材料とプロセス, 7 (1994), 1688.

16) A.Nagasaka, K.Sugimoto and M.Kobayashi: Proc. of Int. Conf. on HSLA Steels '95, ed. by L.Guoxun et al., Beijing, China, (1995), 520. 